Aleh Liashkevich, $\mathrm{PhD}$ in Engineering Science, Director General, Institute BeINIIS RUE (Minsk, Belarus)

\title{
APPLICATION OF ARTIFICIAL NEURAL NETWORKS FOR ASSESSING THE REINFORCEMENT OF REINFORCED-CONCRETE FLOOR SLABS
}

(C) РУП "Институт БелНИИС", 2019

Institute BeINIIS RUE, 2019

\section{ABSTRACT}

In this article, the problem of assessment of working documentation quality in terms of trustworthiness of the calculation of area of main reinforcement of reinforced-concrete structures is reviewed. In spite of development of automated designing systems, no application solutions for fully automated check of quality of working documentation for reinforced-concrete structures as regards sufficiency and necessity of reinforcement of them have been proposed until now. Moreover, this rather routine procedure can be fully automated to exclude the subjective nature of its results. Artificial neural networks (ANN) constitute the most promising mathematical model for this purpose. There are known examples demonstrating the possibility of applying the ANN for various types of calculations and analysis of experimental data for reinforced-concrete structures. In particular, the ANN allows predicting the actual deformation parameters of reinforced-concrete structures with significantly greater accuracy than any of the current national design standards. The article presents the results of calculations of reinforcement and sag for various input parameters using the example of reinforced-concrete slab structure. Using the simplest ANN with one hidden layer over the entire training sample, the predicted values with sufficient accuracy for practical use were obtained. It has been established that ANN makes it possible to predict effectively not only values of the required reinforcement for slab structures, but also their deformation. Within the framework of BIMtechnologies used currently in building design, the use of ANN to assess 
the quality of ready-made design documentation in terms of reinforcement will reduce considerably the cost and time of relevant examinations with significantly higher trustworthiness of their results.

Keywords: reinforced-concrete structures, reinforcement, neural network, artificial intelligence, design documentation.

For citation: Liashkevich A. Application of artificial neural networks for assessing the reinforcement of reinforced-concrete floor slabs. Contemporary Issues of Concrete and Reinforced Concrete: Collected Research Papers. Minsk. Institute BelNIIS. Vol. 11. 2019. pp. 51-62. https://doi.org/10.35579/2076-6033-2019-11-04

Мешкевич Олег Николаевич, канА. техн. наук, генеральный Аиректор, РУП «Институт БелНИИС" (г. Минск, Беларусь)

\section{ИСПОЛЬЗОВАНИЕ ИСКУССТВЕННЫХ НЕЙРОННЫХ СЕТЕЙ АИЯ ОЦЕНКИ АРМИРОВАНИЯ ЖЕАЕЗОБЕТОННЫХ ПАИТ ПЕРЕКРЫТИЯ}

\section{АННОТАЦИЯ}

В статье рассмотрена задача оценки качества рабочей документации в части достоверности расчета площади рабочей арматуры железобетонных конструкций. Несмотря на развитие систем автоматизированного проектирования, до настоящего времени не предложено прикладных решений для полностью автоматизированной проверки качества рабочей документации железобетонных конструкций на предмет достаточности и необходимости их армирования. При этом эта весьма относительно рутинная процедура может быть полностью автоматизирована для исключения субъективного характера ее результатов. Наиболее перспективной математической моделью для этой цели являются искусственные нейронные сети (ИНС). Известны примеры, демонстрирующие возможность прикладного применения ИНС для различного рода расчетов и анализа экспериментальньх 
данных для железобетонных конструкций. В частности, ИНС позволяет с существенно больщей точностью прогнозировать фактические параметры деформирования железобетонных конструкций, чем любые из действующих национальных норм проектирования. В статье на примере железобетонной плитной конструкции приведены результаты расчетов армирования и прогиба при различных значениях входных параметров. С помощью простейшей ИНС с одним скрытым слоем по всей обучающей выборке получены прогнозные значения с достаточной для практического их использования точностью. Установлено, что ИНС позволяет достаточно эффективно прогнозировать не только значения требуемого армирования для плитных конструкций, но и их деформации. В рамках используемых в настоящее время в строительном проектировании ВIМ-технологий применение ИНС для оценки качества готовой проектной документации в части армирования позволит значительно сократить стоимость и сроки соответствующих экспертиз при существенно более высокой достоверности их результатов.

Ключевые слова: железобетонные конструкции, армирование, нейронная сеть, искусственный интеллект, проектная документация.

Для цитирования: Лешкевич, О.Н. Использование искусственных нейронных сетей для оценки армирования железобетонных плит перекрытия / О. Н. Лешкевич // Проблемы современного бетона и железобетона : сб. науч. тр. / Ин-т БелНИИС; редкол.: О. Н. Лешкевич [и др.]. - Минск, 2019. - Вып. 11. - С. 51-62. https://doi.org/10.35579/2076-6033-2019-11-04

\section{INTRODUCTION}

Working drawings of reinforced concrete structures represent a combination of graphic and text documents to be used when performing the construction. Assessment of their quality affects the economic performance and safety of the finished construction site. The costs of checking the working documentation can be very 
significant, therefore as a rule this checking is not performed with the same depth of elaboration, with which the calculations and design were performed. An educated and trained specialist with many years of experience can reveal gross errors after a visual examination of the documentation without performing calculations. To identify all errors, it is necessary to perform the duplicating (independent) calculations and design, which can be implemented in practice for especially critical facilities for economic reasons. Verification of the quality of working documentation, for example, in terms of the adequacy of reinforcement with the use of traditional methods requires a specialist to re-evaluate the reinforced-concrete structures or evaluate them visually, which assumes significant time consumption in the first case and unpredictable quality of the assessment in the second case.

In general, the application of the trained ANN is aimed at construction of a model based on the known data and then use of it to predict the results from the input data. It is actually similar to the approach when performing the visual control of the working documentation: while knowing the topology, load and sectional dimensions, a specialist tries to guess the minimum required amount of reinforcement. Thus, if such an expert assessment by a specialist is possible, it must be fair to assume that a similar or better result can be achieved using the ANN trained to the necessary extent. At the same time, it can be also assumed that after training the system to a certain depth, taking into account the availability of the necessary computing power, its efficiency will be considerably higher than that of a specialist regardless of his/her experience. When performing the visual assessment of the calculation results, a specialist actually summarizes the trends obtained on the basis of previous experience in assessment of other projects or, as a rule, qualitative characteristics of the projects known to him/her. Having performed the calculation of the design, the user on his/her own or with the help of trained personnel checks subjectively his/her own results for quality compliance with logic, common sense and experience gained earlier. Unlike a trained ANN, he/she can use only his/her experience and knowledge so that subjectivity of the assessments will be inevitable. As regards the ANN, it can use a database with information on the results of the work performed by thousands of specialists. 
This study is aimed at establishment of the fundamental possibility of the use of artificial neural networks (ANN) to solve the problem of reinforcement and deformation of statically indeterminable reinforcedconcrete structures with acceptable accuracy.

\section{ANN IN THE PROBLEMS OF CALCULATION OF STRUCTURAL UNITS}

By now, a significant number of research results regarding the applicability of ANN in civil engineering has been published. Their common feature is the search for solutions with the application of the ANN replacing the traditionally applied techniques and algorithms. As a result, potential users have no motivation to abandon traditional applications in support of using ANN, because it would provide no economic or other advantages. The construction norms contain a detailed description of the techniques regulated when designing the structural units, which is a serious obstacle to the application of other mathematical methods. Here the use of the ANN instead of the finite element method to solve individual problems of structural mechanics with linear characteristics of materials shows high accuracy of the solution [1]. Moreover, the comparative analysis of the results of calculations of reinforced-concrete statically determinable beams obtained according to the techniques of construction norms and, as a result, of applying the trained ANN with verification according to the data of samples of reinforced-concrete structures has shown that the results obtained with the use of the ANN have higher accuracy [2]. When evaluating the results of tests of reinforced-concrete frames, the accuracy is even higher in comparison with that provided in the design standards: the error when using the ANN is $6.8 \%$ versus 30 $64 \%$ provided in various national design standards [3].

At present, attempts are undertaken to develop algorithms implementing the ANN in order to use them instead of the finite element method for analysis of systems with materials having a high degree of non-linearity. These works are primarily aimed at reduction of labor intensity of preparation of design models [4].

At present, there is no publicly available ANN-based software for assessment or control of reinforced-concrete structures. At first, the problem consists in the complexity of algorithmization of the ANN in respect of calculations of reinforced-concretestructures, because reinforced 
concrete is a composite material having unique deformation features described solely on the basis of empirical data. In accordance with the universal approximation theorem, the direct-communication ANN with one hidden layer can approximate any continuous multivariable function with any accuracy [5]. To calculate the reinforced concrete structures, the methods, in which the dependences of deformations, forces, and reinforcement on the load are not continuous functions, are used. The conditional break points are determined by the nature of cracking in the sections of reinforced-concrete elements and, at the same time, by nonlinearity of the diagrams of deformation of concrete and reinforcement. In addition, impossibility of construction of such functional dependencies both for an arbitrary section of a reinforced-concrete element and for a specific section, because their form is affected by both the magnitude of the external load and the ratio of its components, is also a complicating factor [6]. Thus, the applicability of ANN in the general case has been proved by now for solving problems of structural mechanics, design, optimization, research and diagnostics of structures and systems being under the action of any static and dynamic loads [7]. However, the almost complete absence of real application of them is explained by the complexity of formalization of tasks, while the advantages over traditional methods and algorithms are not obvious. The most significant obstacle consists simply in the lack of practical need for using the ANN in the civil design, because the vast majority of types of calculations in construction are regulated by standards and norms, thereby leaving no tasks for other mathematical methods within the existing design technology.

\section{FEATURES OF APPLICATION OF THE ANN IN RESPECT OF THE CALCULATIONS OF STATICALLY UNDETERMINABLE FLOOR SLABS}

The main parameters in the quality control of designing the reinforced-concrete structures are the reinforcement area, type and location of the corresponding structural elements as those affecting the strength and safety of the reinforced-concrete structure to the really largest extent. Although the basis of any algorithms for calculating reinforced concrete structures is an unambiguous representation of the physical essence of their work under the action of loads, the algorithms established by various national design standards can lead 
to qualitatively and quantitatively different results. It means that there could occur situations when the same structure designed correctly according to some national design standards, may be considered poorly designed according to other national design standards. In addition, individual parameters of the reinforcement of floor slabs are not independent of each other; their mutual influence is determined as a rule by the design requirements set forth by national design standards. Thus, the corresponding expert system as a part of the boundary conditions shall take into account the design standards. Consequently, the expert system for each country needs in fact to be trained separately. In addition, it is desirable to take into account the design constraints obtained from assessment of testing a large number of experimental structures or experience of operation of finished construction objects.

The floor slabs have different design reinforcement even within the same span, that is the design reinforcement will be individual in each node when being calculated by the finite element method that will require an almost infinite volume of the training sample. In practice, the reinforcement adopted in the project with due account for the size range can be partially or completely unified over the entire structure area. For this reason, the training sample shall be formed on the basis of the design reinforcement, taking into account the size range stocks and restrictions.

The greatest difficulty in training the ANN is the multivariance of the solution of the problem of reinforcing the reinforced-concrete structure with the same initial data. Algorithms for calculating the reinforcement of flexible structures allow for existence of more than one solution to enable various optimizations of the total reinforcement of the upper and lower zones of flexible structures.

\section{CALCULATION OF REINFORCED-CONCRETE FLOOR SLABS}

To ensure the necessary accuracy of operation of the ANN, the machine learning models work as a rule with huge amounts of data; however, there are no necessary databases in the construction. Due to this circumstance, the calculations required for demonstration of the possibility to train the models, that are necessary for evaluating the calculations of reinforced-concrete structures are performed using the 
example of a rectangular reinforced-concrete slab structure supported on four points (Figure 1).

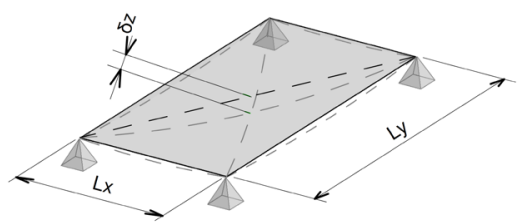

a) sag at the span centre

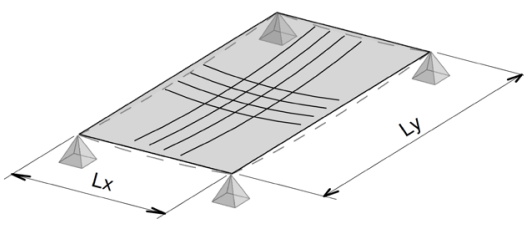

b) bottom reinforcement at the span centre

Figure 1. Structural design and output parameters

The following input parameters were used for training the ANN:

1) $\mathrm{L}_{\mathrm{x}}$ - dimension in the direction of the $X$ axis (range from 4.5 to $8 \mathrm{~m}$ );

2) $\mathrm{L}_{\mathrm{y}}$ - dimension in the direction of the $Y$ axis (range from 4.5 to $8 \mathrm{~m}$ );

3) $\mathrm{q}$ - load distributed over the area (range from 5 to $10 \mathrm{kN} / \mathrm{m}^{2}$ ).

4) $\mathrm{d}$ - floor slab thickness (range from 0.16 to $0.30 \mathrm{~m}$ ).

The calculated reinforcement at the span centre in mutually perpendicular directions over the bottom of the slab $\left(A_{s x}\right.$ and $\left.A_{s y}\right)$ as well as the maximum calculated sag of the slab $d_{z}$ were taken as output parameters.

Since there is no straightforward method for choosing the number of hidden layers and neurons in them, and since this work is not aimed at finding the optimal structure for the problems under study, we use the simplest ANN with ten neurons in one hidden layer (Figure 2).

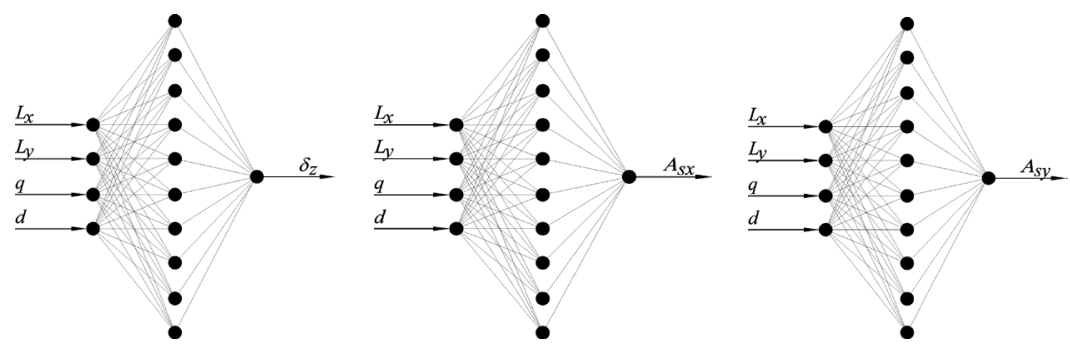

a)

b)

c)

Figure 2. Schemes of the ANN 
The training sample was obtained by the calculation with the use of the software implementing the finite-element method. The reinforcement is calculated in accordance with the requirements of EN 1992-1-1 Eurocode 2. The table presents all the input and output parameters as well as their predicted values based on the input values of the training sample.

Table 1

Input, output and predicted values of the parameters

\begin{tabular}{|c|c|c|c|c|c|c|c|c|c|c|c|c|c|}
\hline \multirow{2}{*}{$\begin{array}{c}\text { Item } \\
\text { No. }\end{array}$} & \multicolumn{4}{|c|}{ Variables } & \multicolumn{3}{|c|}{ Training sample } & \multicolumn{3}{|c|}{ Predicted values } & \multicolumn{3}{|c|}{ Relative error, $\%$} \\
\hline & Lx & Ly & d & $\mathbf{q}$ & $\delta \mathrm{z}$ & Asx & Asy & $\delta z$ & Asx & Asy & $\delta \mathrm{z}$ & Asx & Asy \\
\hline 1 & 6 & 6 & 0.16 & 5 & 25.8 & 7.05 & 7.05 & 26.7 & 7.13 & 6.85 & 3.4 & 1.2 & 3.0 \\
\hline 2 & 6 & 6 & 0.18 & 5 & 19.2 & 6.23 & 6.23 & 19.9 & 6.44 & 6.35 & 3.5 & 3.2 & 1.8 \\
\hline 3 & 6 & 6 & 0.2 & 5 & 14.7 & 5.68 & 5.68 & 15.4 & 5.86 & 5.89 & 4.5 & 3.0 & 3.6 \\
\hline 4 & 6 & 6 & 0.22 & 5 & 11.7 & 5.26 & 5.26 & 12.5 & 5.38 & 5.48 & 6.4 & 2.3 & 4.0 \\
\hline 5 & 6 & 6 & 0.3 & 5 & 5.5 & 4.27 & 4.27 & 5.2 & 4.19 & 4.08 & 6.1 & 2.0 & 4.7 \\
\hline 6 & 6 & 6 & 0.16 & 7 & 31.5 & 8.88 & 8.88 & 31.7 & 8.48 & 8.19 & 0.7 & 4.7 & 8.5 \\
\hline 7 & 6 & 6 & 0.18 & 7 & 23.2 & 7.68 & 7.68 & 23.1 & 7.64 & 7.50 & 0.6 & 0.5 & 2.4 \\
\hline 8 & 6 & 6 & 0.2 & 7 & 17.7 & 6.87 & 6.87 & 16.6 & 6.92 & 6.91 & 6.9 & 0.8 & 0.6 \\
\hline 9 & 6 & 6 & 0.22 & 7 & 13.9 & 6.3 & 6.30 & 12.5 & 6.32 & 6.39 & 11.5 & 0.4 & 1.4 \\
\hline 10 & 6 & 6 & 0.3 & 7 & 6.4 & 4.97 & 4.97 & 5.1 & 4.81 & 4.75 & 25.3 & 3.2 & 4.7 \\
\hline 11 & 6 & 6 & 0.16 & 10 & 40.1 & 11.74 & 11.74 & 39.1 & 11.25 & 11.36 & 2.5 & 4.4 & 3.4 \\
\hline 12 & 6 & 6 & 0.18 & 10 & 29.2 & 9.99 & 9.99 & 31.8 & 10.12 & 10.13 & 8.2 & 1.3 & 1.4 \\
\hline 13 & 6 & 6 & 0.2 & 10 & 22.1 & 8.76 & 8.76 & 23.9 & 9.12 & 9.10 & 7.4 & 3.9 & 3.7 \\
\hline 14 & 6 & 6 & 0.22 & 10 & 17.2 & 7.89 & 7.89 & 17.5 & 8.25 & 8.24 & 1.7 & 4.4 & 4.2 \\
\hline 15 & 6 & 6 & 0.3 & 10 & 7.7 & 6.02 & 6.02 & 8.1 & 6.00 & 5.85 & 4.7 & 0.4 & 2.9 \\
\hline 16 & 6 & 6 & 0.3 & 10 & 7.7 & 6.02 & 6.02 & 8.1 & 6.00 & 5.85 & 4.7 & 0.4 & 2.9 \\
\hline 17 & 5 & 6 & 0.3 & 10 & 5.8 & 3.93 & 6.31 & 6.7 & 3.92 & 6.10 & 12.9 & 0.3 & 3.5 \\
\hline 18 & 5 & 5 & 0.2 & 10 & 10.7 & 5.93 & 5.93 & 10.2 & 5.95 & 5.99 & 4.4 & 0.4 & 1.0 \\
\hline 19 & 5 & 5 & 0.2 & 5 & 7.1 & 3.9 & 3.90 & 7.5 & 4.17 & 3.90 & 5.7 & 6.6 & 0.1 \\
\hline 20 & 5 & 3 & 0.18 & 5 & 5.3 & 4.58 & 1.20 & 5.3 & 4.34 & 1.28 & 0.4 & 5.6 & 6.0 \\
\hline 21 & 8 & 4 & 0.24 & 7 & 19.5 & 11.46 & 2.29 & 15.6 & 11.55 & 1.96 & 25.1 & 0.8 & 17.0 \\
\hline 22 & 4 & 8 & 0.24 & 7 & 19.5 & 2.26 & 11.46 & 17.3 & 2.13 & 11.37 & 12.6 & 6.0 & 0.8 \\
\hline 23 & 6 & 3 & 0.2 & 7 & 9.8 & 7.38 & 1.48 & 12.5 & 7.19 & 1.62 & 21.6 & 2.6 & 8.9 \\
\hline 24 & 3 & 6 & 0.2 & 7 & 9.8 & 1.48 & 7.38 & 12.1 & 1.52 & 7.54 & 18.8 & 2.5 & 2.1 \\
\hline 25 & 6 & 8 & 0.22 & 5 & 24.4 & 4.88 & 10.39 & 23.8 & 4.50 & 10.46 & 2.6 & 8.4 & 0.7 \\
\hline 26 & 8 & 6 & 0.22 & 5 & 24.4 & 10.39 & 4.88 & 26.2 & 10.27 & 4.90 & 6.9 & 1.1 & 0.4 \\
\hline 27 & 5 & 7 & 0.2 & 5 & 17.3 & 3.53 & 8.52 & 17.9 & 3.54 & 8.55 & 3.5 & 0.2 & 0.4 \\
\hline 28 & 7 & 5 & 0.2 & 5 & 17.3 & 8.52 & 3.53 & 16.1 & 8.46 & 3.35 & 7.5 & 0.7 & 5.4 \\
\hline 29 & 7 & 5.5 & 0.2 & 6 & 20.8 & 8.98 & 4.74 & 22.4 & 9.05 & 4.87 & 7.1 & 0.8 & 2.7 \\
\hline
\end{tabular}


Table 1 (ending)

\begin{tabular}{|c|cccc|ccc|ccc|ccc|}
\hline Item & \multicolumn{4}{|c|}{ Variables } & \multicolumn{3}{|c|}{ Training sample } & \multicolumn{3}{c|}{ Predicted values } & \multicolumn{3}{c|}{ Relative error, \% } \\
\cline { 2 - 14 } No. & Lx & Ly & $\mathbf{d}$ & $\mathbf{q}$ & $\boldsymbol{\delta} \mathbf{z}$ & Asx & Asy & $\boldsymbol{\delta z}$ & Asx & Asy & $\boldsymbol{\delta} \mathbf{z}$ & Asx & Asy \\
\hline 30 & 5.5 & 7 & 0.2 & 6 & 20.8 & 4.74 & 8.98 & 20.3 & 4.62 & 9.14 & 2.3 & 2.6 & 1.7 \\
31 & 7 & 5.5 & 0.24 & 9 & 16.5 & 9.72 & 5.14 & 15.4 & 9.62 & 5.32 & 6.8 & 1.0 & 3.4 \\
32 & 5.5 & 7 & 0.24 & 9 & 16.5 & 5.14 & 9.72 & 14.8 & 4.95 & 10.01 & 11.6 & 3.9 & 2.9 \\
33 & 7 & 5.5 & 0.18 & 5.5 & 25.9 & 9.46 & 4.96 & 23.8 & 9.64 & 5.06 & 8.9 & 1.9 & 1.9 \\
34 & 5.5 & 7 & 0.18 & 5.5 & 25.9 & 4.96 & 9.46 & 26.7 & 4.91 & 9.46 & 3.0 & 1.1 & 0.0 \\
35 & 8 & 4.5 & 0.18 & 7.5 & 43.2 & 16.03 & 3.36 & 40.0 & 16.20 & 3.46 & 7.9 & 1.0 & 3.0 \\
36 & 4.5 & 8 & 0.18 & 7.5 & 43.2 & 3.36 & 16.03 & 42.4 & 3.63 & 16.08 & 1.9 & 7.4 & 0.3 \\
37 & 8 & 4.5 & 0.26 & 7.5 & 16.8 & 11.08 & 2.37 & 18.9 & 10.90 & 2.44 & 11.3 & 1.7 & 2.9 \\
38 & 4.5 & 8 & 0.26 & 7.5 & 16.8 & 2.37 & 11.08 & 17.0 & 2.60 & 11.00 & 1.0 & 8.8 & 0.7 \\
39 & 8 & 4.5 & 0.3 & 10 & 13.7 & 11.7 & 2.49 & 12.6 & 11.64 & 2.56 & 8.4 & 0.6 & 2.9 \\
40 & 4.5 & 8 & 0.3 & 10 & 13.7 & 2.49 & 11.70 & 13.0 & 2.38 & 11.63 & 5.1 & 4.6 & 0.6 \\
\hline
\end{tabular}

For the purposes of structural design, the obtained average relative error for all the studied output parameters can be considered as extremely small, not affecting the result of the structural analysis. In the general case, the solutions with such accuracy allow considering at least two categories of problems:

- calculation of the volume of basic building materials (concrete and reinforcement) to be solved at the stage of preliminary assessment of the volume of investments;

- sufficiency and non-redundancy of the use of, first of all, reinforcement to be solved at the stage of quality control of the finished design documentation.

\section{CONCLUSION}

1. The hypothesis of the possibility of using the ANN for qualitative and quantitative assessment of the adopted reinforcement in the design of reinforced-concrete floor slabs in principle is confirmed.

2 . The use of other mathematical models in the design of reinforced-concrete structures in addition to design standards and structural mechanics methods provides an opportunity to solve a radically new class of problems that have not been earlier applied in practice. 
3. The use of the ANN in designing the reinforced-concrete structures in addition to traditional methods will significantly increase the quality and efficiency of design work.

4. Using the ANN opens up the possibility of developing a qualitatively different software increasing considerably the efficiency of design work in construction, while reducing significantly the need for qualified engineering personnel. The presented approach to assessing the quality of reinforcement can be applied both independently and in advanced technologies of computerized development of working documentation.

5. Taking into account the universal introduction of BIM technologies, the use of ANN to assess the quality of ready-made project documentation regarding the reinforcement will reduce its duration from weeks to seconds with considerably higher reliability of the results.

\section{REFERENCES}

1. Javadi A. A., Tan T. P., Zhang M. X. (2002) Neural network for constitutive modelling in finite element analysis. Computer Assisted Mechanics and Engineering Sciences. 2003. Vol. 10. pp. 523-529.

2. Kaczmarek M., Szymanska A. (2016) Application of artificial neural networks to predict the deflections of reinforced concrete beams. Studia Geotechnica et Mechanica. 2016. Vol. 38. No. 2. pp. 37-46.

3. Li L., Zheng W., Wang Y.(2019) Prediction of Moment Redistribution in Statically Indeterminate Reinforced Concrete Structures Using Artificial Neural Network and Support Vector Regression. Applied Sciences. 2019. 9(1):28.

4. Roewer-Despres F., Khan N., Stavness I. (2018) Towards finite element simulation using deep learning. Papers of the 15th International Symposium on Computer Methods in Biomechanics and Biomedical Engineering. 2018. Mode of access:http://cmbbe2018.tecnico.ulisboa.pt/pen_cmbbe2018/ pdf/EB_PAPERS/CMBBE2018_paper_89.pdf. Date of access: 25.11.2019 
5. Cybenko G. V. (1989) Approximation by Superpositions of a Sigmoidal function. Mathematics of Control Signals and Systems. 1989. T. 2, № 4. pp. 303-314.

6. Lazovsky D. N., Glukhov D. O., Liashkevich O. N. Metodika rascheta staticheski neopredelimykh sterzhnevykh zhelezobetonny$k h$ konstrukciy [Technique of calculation of statically indeterminable reinforced concrete structures]. Bulletin of the Polotsk State University. Series B, Applied sciences: Scientific theoretical journal. Novopolotsk: PSU. 2004. No.1. pp. 66-73. (rus)

7. Maximova O. M. Razvitiye i primeneniye neyrosetevykh tekhnologiy dlia zadach mekhaniki i stroitelnykh konstrukciy [Development and application of neural network technologies for the tasks of mechanics and building structures]. Bulletin of the Irkutsk State Technical University. Irkutsk: IrSTU. 2013. № 8 (79). pp. 81-89. (rus)

Received: 27.11.2019 